\title{
Identification of Free Radicals Induced by Gamma Irradiation in Amino Acid Derivatives
}

\author{
Murat Aydin* \\ Faculty of Education, Adlyaman University, TR 02030-Adlyaman, Turkey
}

(Received on 14 December, 2009)

\begin{abstract}
Powders of N-acetyl-L-leucine and N-methyl-L-glutamic acid were gamma irradiated and the free radicals formed were investigated at room temperature by electron paramagnetic resonance technique. The free radicals formed in compounds were attributed to the $\left(\mathrm{CH}_{3}\right)_{2} \mathrm{CCH}_{2} \mathrm{CH}(\mathrm{NHCOCH}) \mathrm{COOH}$ and $\mathrm{HOOCCH}_{2} \mathrm{CH}_{2} \mathrm{C}\left(\mathrm{NHCH}_{3}\right) \mathrm{COOH}$ radicals respectively. Both radicals are very stable and we could observe them for five months without almost intensity diminution at room temperature. The $g$ values of the radicals and the hyperfine structure constants of the free electron with nearby protons and ${ }^{14} \mathrm{~N}$ nucleus were determined. The results were found to be in good agreement with the existing literature data.
\end{abstract}

Keywords: Gamma irradiation, EPR, Free radicals, Leucine, Glutamic acid.

\section{INTRODUCTION}

Free radicals are important constituents of many reaction mechanisms and they significantly contribute to normal functioning of the organisms as well as to development of pathological process [1-4].

The electron paramagnetic resonance (EPR) has been widely used for the identification of irradiation damage centers in many substances including amino acid and their derivatives [5-15]. In previous study, Almanov et.al. [16] were showed that two types of radicals were observed in gamma irradiated single crystal of $\mathrm{N}$-acetyl-L-leucine at room temperature; $\left(\mathrm{CH}_{3}\right)_{2} \dot{\mathrm{C}} \mathrm{CH}_{2} \mathrm{CH}\left(\mathrm{NHCOCH}_{3}\right) \mathrm{COOH}$ and $\left(\mathrm{CH}_{3}\right)_{2} \mathrm{CHCH}_{2} \mathrm{C}\left(\mathrm{NHCOCH}_{3}\right) \mathrm{COOH}$. Furthermore, $\mathrm{N}$-carbamoyl-L-glutamic acid were gamma irradiated and studied at room temperature with EPR [17]. The radiation damage center was attributed to the $\mathrm{HOOCCH}_{2} \mathrm{CH}_{2} \dot{\mathrm{C}}\left(\mathrm{NHCONH}_{2}\right) \mathrm{COOH}$ radical.

Leucine and glutamic acid provide many benefits to the body. Leucine is important for the regulation of protein synthesis and is essential in the building of muscle tissue. Glutamic acid is a potential source of energy and it is important in brain metabolisms. To our knowledge $\mathrm{N}$-acetyl-L-leucine, $\left(\mathrm{CH}_{3}\right)_{2} \mathrm{CCHCH}_{2} \mathrm{CH}\left(\mathrm{NHCOCH}_{3}\right) \mathrm{COOH}$, and N-methyl-Lglutamic acid, $\mathrm{HOOCCH} \mathrm{CH}_{2} \mathrm{CH}\left(\mathrm{NHCH}_{3}\right) \mathrm{COOH}$, powders have been not investigated. Therefore it is the purpose of this work to identify and check the stabilities of the radical species formed in these two amino acid derivatives by gamma irradiation at room temperature.

\section{EXPERIMENTAL}

The samples used in this study were obtained from commercial sources. Powder samples of the compounds were exposed to gamma-irradiation from ${ }^{60} \mathrm{Co}$ gamma-ray source (Nordion-Canada model JS 9600) at dose rate of $2 \mathrm{kGy} / \mathrm{h}$ for a total of $10 \mathrm{~h}$ at room temperature. After irradiation, samples were kept in plastic bags at room temperature in the dark. The spectra of samples were recorded by putting the sample in quartz sample tube. The EPR measurements

\footnotetext{
*Electronic address: muraydinategmail.com
}

was carried out in a Varian model X-band E-109C EPR spectrometer at room temperature. The modulation amplitude was below $5 \cdot 10^{-2} \mathrm{mT}$ and the microwave power was 2 $\mathrm{mW}$. The $g$ factors were found by comparison with a dipenhylpicrylhydrazyl (DPPH) sample with of $\mathrm{g}=2.0036$ [18, 19]. The spectrum simulations were made using McKelvey's programs [20].

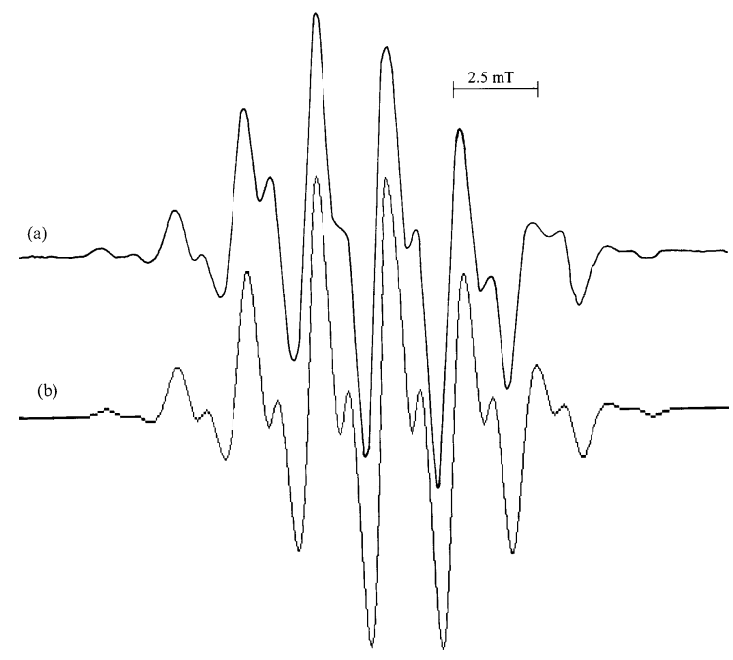

FIG. 1: (a) The EPR spectrum of gamma irradiated NAL powder at room temperature, (b) simulation form of the spectrum using $a_{(\mathrm{CH} 3)^{2}}=2.13 \mathrm{mT}, a_{\beta}^{(1)}=2.13 \mathrm{mT}, a_{\beta}^{(2)}=0.73 \mathrm{mT}$ and linewidth $0.40 \mathrm{mT}$.

\section{RESULTS AND DISCUSSION}

Before the gamma irradiation of powders of $\mathrm{N}$-acetylL-leucine (NAL) and N-methyl-L-glutamic acid (NMGA), samples did not give any EPR signals. The EPR spectra of gamma irradiated samples are shown in figures 1,2 .

The gamma irradiated powder of NAL gives the spectrum shown in figure $1 \mathrm{a}$ at room temperature. This spectrum can easily be thought as consisting of 8 sets of lines with an intensity distribution of $1: 7: 21: 35: 35: 21: 7: 1$, in which the unpaired electron interacts seven equivalent protons with coupling constant equal to $2.13 \mathrm{mT}$. Then each of these 8 


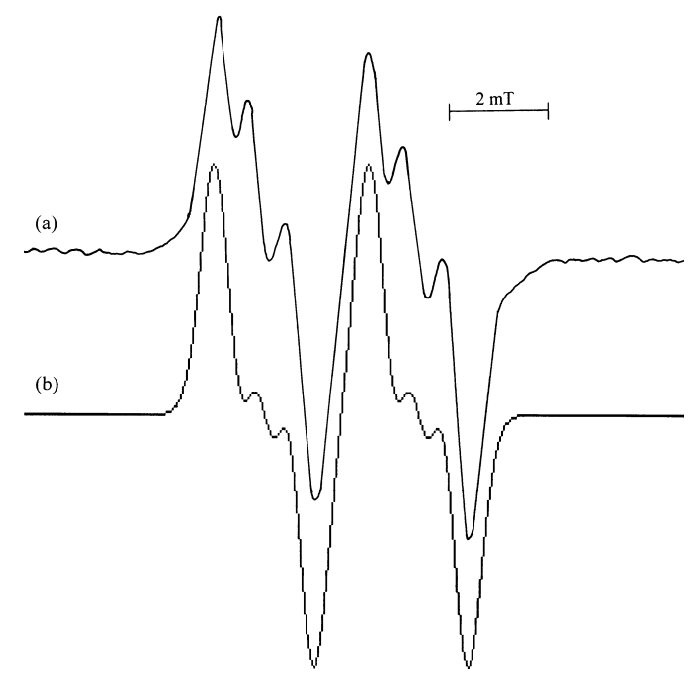

FIG. 2: (a) The EPR spectrum of gamma irradiated NMGA powder at room temperature, (b) simulation form of the spectrum using $a_{\beta}^{(1)}=3.00 \mathrm{mT}, a_{N}=0.65 \mathrm{mT}$ and linewidth $0.40 \mathrm{mT}$.

lines are also doublets with a splitting spacing of $0.73 \mathrm{mT}$. We may assume that this EPR spectrum belongs to the $\left(\mathrm{CH}_{3}\right)_{2} \dot{\mathrm{C}} \mathrm{CH}_{2} \mathrm{CH}\left(\mathrm{NHCOCH}_{3}\right) \mathrm{COOH}$ radical. It is also determined that the hyperfine coupling constants of the protons of the two rotating methyl groups and one of the methylene protons is similar in value $2.13 \mathrm{mT}$ and the coupling with the second methylene proton is small in value $0.73 \mathrm{mT}$. The measured value of the $g$ factor is $2.0032 \pm 0.0005$. The simulation of the spectrum, with the above given values, is shown in figure $1 b$.

The $g$ value and the hyperfine constants of methyl protons of the radical discussed here agree well with some other literature data [21-24]. In the gamma irradiated N-formylL-leucine, at room temperature, the free radical has been attributed to the $\left(\mathrm{CH}_{3}\right)_{2} \dot{\mathrm{C}} \mathrm{CH}_{2} \mathrm{CH}(\mathrm{NHCOH}) \mathrm{CO}_{2}$ radical [25]. This is similar to our proposed radical and the reported values of $a_{(\mathrm{CH} 3)_{2}}=2.4 \mathrm{mT}$ and $a_{\beta}^{(1)}=2.40 \mathrm{mT}$ are in good agreement with our results. A radical similar to this has been observed in the gamma irradiated L-leucine methyl ester hydrochloride powders [26], but the hyperfine coupling constants of methylene protons (3.80 and $0.9 \mathrm{mT}$ ) are higher than the values reported here. Similar values of the hyperfine coupling constants of the methylene protons have been found in the gamma irradiated $\mathrm{Al}_{6} \mathrm{O}_{4}(\mathrm{OH})_{10}$ (leucine) $\cdot 5 \mathrm{H}_{2} \mathrm{O}$ system as $2.30 \mathrm{mT}$ and $0.70 \mathrm{mT}$ [27]. We can state that the $\left(\mathrm{CH}_{3}\right)_{2} \dot{\mathrm{C} C H} \mathrm{CH}_{2} \mathrm{CH}\left(\mathrm{NHCOCH}_{3}\right) \mathrm{COOH}$ radical is obtained by the removal of hydrogen atom from the tertiary carbon atom of the NAL.

The characteristic stable EPR spectrum of the NMGA powder at room temperature is shown in figure $2 \mathrm{a}$. This spectrum is a doublet of triplets. When the spectrum is ex- amined thoroughly, it can be seen that it consists of a doublet with a spacing of $3.00 \mathrm{mT}$. Then each line of the doublet is further subdivided into 3 lines of spacing $0.65 \mathrm{mT}$. These indicate the hyperfine coupling of the unpaired electron with one of the methylene protons and a nitrogen nucleus $(I=1)$. Therefore we attribute the species to the radical $\mathrm{HOOCCH}_{2} \mathrm{CH}_{2} \dot{C}\left(\mathrm{NHCH}_{3}\right) \mathrm{COOH}$. The $g$ values of this radical is measured as $g=2.0027 \pm 0.0005$. A simulation of the spectrum is shown in figure $2 b$, using the hyperfine coupling constants $a_{\beta}^{(1)}=3.00 \mathrm{mT}$ and $a_{N}=$ $0.65 \mathrm{mT}$. The experimental and simulated EPR spectrum is found to agree well with each other. The above given values of the hyperfine coupling constant agree well with some other literature values of amine radicals [28-32]. Single crystal of the gamma irradiated $\mathrm{N} \alpha$-acetyl L-glutamic acid has been investigated at room temperature and the radiation damage centre of this sample has attributed to the $\mathrm{HOOCCH}_{2} \mathrm{CH}_{2} \dot{\mathrm{C}}\left(\mathrm{NHCOCH}_{3}\right) \mathrm{COOH}$ radical [33]. The reported average values of the hyperfine constants are $a_{\beta}^{(1)}=$ $3.65 \mathrm{mT}$ and $a_{N}=0.56 \mathrm{mT}$. This radical and the reported EPR parameters are fairly similar to the radical obtained from NMGA.

In the $\mathrm{HOOCCH}_{2} \mathrm{CH}_{2} \dot{\mathrm{C}}\left(\mathrm{NHCH}_{3}\right) \mathrm{COOH}$ radical, only one proton of the methylene group show a resolvable coupling. Other proton of the methylene group lies in the nodal plane of the $\mathrm{p} \pi$ orbital and thus produces no hyperfine coupling [34$35]$. The coupling to the $\beta$-proton in this radical occurs primarily through hyperconjugation, and the magnitude of the splitting depends on the dihedral angle $\theta$ between the $\mathrm{C}-\mathrm{H}$ bond and the $\mathrm{p} \pi$ orbital which contains the unpaired electron. The $\beta$-proton coupling constant is given by [36]

$$
a_{\beta}=B_{0}+B_{1} \cos ^{2} \theta \text {. }
$$

In this equation the constants $B_{0}$ and $B_{1}$ have been experimentally determined as 0.32 and $4.36 \mathrm{mT}$, respectively [33]. Substitution of the observed value of $a_{\beta}^{(1)}=3.00 \mathrm{mT}$ into equation (1) yields a value of $38^{0}$ for $\theta$. The much smaller value of the hyperfine coupling constant $(<0.4 \mathrm{mT})$ of the second proton of the methylene group must be due to its $\theta$ value of $90^{\circ} \mathrm{m}$ [33]. Hence we can state that the $\beta$-proton in this radical rotates about $C_{\alpha}-C_{\beta}$ and this rotation of the $\beta$-proton exists at room temperature.

\section{CONCLUSION}

The gamma irradiated NAL and NMGA samples indicated the inducement of $\left(\mathrm{CH}_{3}\right)_{2} \dot{\mathrm{CCH}}_{2} \mathrm{CH}\left(\mathrm{NHCOCH}_{3}\right) \mathrm{COOH}$ alkyl type and $\mathrm{HOOCCH} \mathrm{CH}_{2} \mathrm{C}\left(\mathrm{NHCH}_{3}\right) \mathrm{COOH}$ amine type radicals respectively. The EPR parameters and the structure of the radicals could be determined. The measurements of magnetic properties of these radicals can be helpful in the study of similar radicals found in biological systems. 
Bimol. Spectrosc., 63, 840 (2006).

[3] J. Kiljunen, E. Popov, H. Kunttu and J. Eloranta, J. Chem. Phys., 130, 164504 (2009)

[4] N. Metreveli, L. Namicheishvili, K. Jariashvili, M. Dgebuadze and E. Chikvaidze, J. Photochem. Photobiol. B: Biol., 93, 61 (2008).

[5] H. Shields, P. Hamrick and D. Delaigle, J. Chem. Phys., 46, 3649 (1967).

[6] D.M. Zengin, M. Birey, H. Aktaş and A. Hancer, Z. Naturforsch., 51a, 895 (1996).

[7] N.D. Yordanov and K. Ranguelova, Spectrochim. Acta. A., 56, 373 (2000).

[8] N.D. Yordanov and B. Mladenova, Radiat. Phys. Chem., 60, 191 (2001).

[9] L. Bachmann, A.B. dos Santos, S. Baffa, D.M. Zezell, Spectroscopy Lett., 36, 487, (2003).

[10] M. Tabak, D. de Sousa Neto and C.E.G. Salmon, Braz. J. Phys., 36, 83 (2006).

[11] Kinoshita, L. Figuty and O. Baffa, Braz. J. Phys., 36, 93 (2006).

[12] F. Chen, C.F.O. Graeff and O. Baffa, Nucl. Instr. and Meth., Phys. Research B, 264, 277 (2007).

[13] N.D. Yordanov and K. Aleksieva, Radiat. Phys. Chem., 78, 213 (2009).

[14] M. Aydin, M.H. Baskan and Y. Osmanoglu, Braz. J. Phys., 39, 583 (2009).

[15] N.D. Yordanov, O. Lagunov and K. Dimov, Radiat. Phys. Chem., 78, 277 (2009).

[16] G.A. Almanov, G.A. Bogdanchikov, P.V. Schastnev and Y.V. Gatilov, High Energy Chem., 20, 430 (1986).

[17] Ş. Osmanoğlu, M. Aydin and M.H. Başkan, Z. Naturforsch., 60a, 549 (2005).

[18] N. D. Yordanov and A. Christova, Appl. Mag. Res., 6, 341
(1994).

[19] N. D. Yordanov, Appl. Mag. Res., 10, 339 (1996).

[20] R. D. McKelvey, J. Chem. Educ., 64, 497 (1987).

[21] V.N. Laslo, T.A. Himdan and H. Bilinski, Radiat. Resear., 132, 1 (1992).

[22] Ḑ. Osmanoğu and M. H. Başkan, Z. Naturforsch., 58a, 290 (2003).

[23] Ş. Osmanoğlu and M. H. Başkan, J. Chem. Research (s), 26 (2003).

[24] M.H. Başkan, Ş. Osmanoglu and I.Y. Dicle, Radiat. Eff. Defects Solids, 164, 673 (2009).

[25] G.A. Almanov, G.A. Bogdanchikov and O. M. Usov, J. Structural Chem., 36, 912 (1989).

[26] I. Kartal, F. Köksal and F. Ucun, J. Chem. Research (s), 118 (1996).

[27] V.N. Laslo, T.A. Himdan and H. Bilinski, Radiat. Phys. Chem., 37, 169 (1991)

[28] D.E. Wood and R. V. Lloyd, J. Chem. Phys., 53, 3932 (1970).

[29] P. Neta and R. W. Fessenden, J. Phys.Chem., 75, 738 (1971).

[30] D.M. Close, G.W. Fouse and W.A. Bernhard, J. Chem. Phys., 66, 1534 (1977)

[31] R. Köseoğlu, E. Köseoğlu and F. Köksal, App. Radiat. Isot., 58, 63 (2003).

[32] M. Aydin, Y.E. Osmanoğlu and M.H. Başkan, Radiat. Eff. Defects Solids, 163, 47 (2008).

[33] F. Köksal, S. Osmanoglu, I. Kartal and F. Ucun, Radiat. Phys. Chem., 49, 537 (1997).

[34] D.H. Whiffen, Pure Appl. Chem., 4, 185 (1962).

[35] W. Bernhard and W. Snipes, Proc. Natl. Acad. Sci. U S A., 59, 1038 (1968).

[36] J.R. Morton, Chem. Rev., 64, 453 (1964). 